Click www.researchjournal.co.in/online/subdetail.html to purchase.

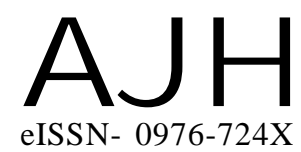

Received : 04.06.2016

Accepted : 30.11 .2016
THEASIAN JOURNAL OF HORTICULTURE

Volume 11 | Issue 2 | December, 2016 | 420-422

Visit us -www.researchjournal.co.in

RESEARCH NOTE

DOI : 10.15740/HAS/TAJH/11.2/420-422

\title{
Micropropagation of Solanum lycopersicum (Utkal kumari ) - a variety of tomato cultiver
}

PALLAVI D. JOGI AND I.C. MOHANTY ${ }^{1}$

KEY WORDS : Micropropagation, Tomato cultiver

HOW TO CITE THIS ARTICLE : Jogi, Pallavi D. and Mohanty, I.C. (2016). Micropropagation of Solanum lycopersicum (Utkal kumari ) - a variety of tomato cultiver. Asian J. Hort., 11(2) : 420-422, DOI : 10.15740/HAS/TAJH/11.2/420-422.

Author for correspondence :

PALLAVI D. JOGI

Orissa University of Agriculture

and Technology, BHUBANESWAR

(ODISHA) INDIA 